\title{
PENERAPAN STRATEGI HEURISTIK PADA PEMBELAJARAN FISIKA TERHADAP HASIL BELAJAR FISIKA SISWA DI KELAS X SMAN 9 PADANG
}

\author{
Fitri Jayanti ${ }^{1}$, Hidayati ${ }^{2}$ \\ ${ }^{1}$ Guru SMP Muhammadiyah 1 Padang \\ ${ }^{2}$ Universitas Negeri Padang \\ Email: rava@yahoo.com \\ http://dx.doi.org/10.22202/jrfes.2015.v1i2.1401
}

\begin{abstract}
This research is motivated by the fact that learning in school physics teacher still studying physics center and the results are still low, but the physics is a science that underlies the development of science and technology. Various attempts have been made by the government, but the results have not been up, one dintaranya is the use of learning strategies that are student center and interesting. One form of appropriate learning strategies used in teaching physics to improve learning outcomes physics is heuristic strategies. This type of research is a quasi experimental research using Randomized Control Group Only Design. The sample selection using purposive sampling technique. The instrument of collecting data in this study is a written test in the form of 25 multiple choice questions for cognitive, scoring rubric for psychomotor, and affective domain format for the assessment. Based on data analysis that has been done, then found the average value of physics students in the cognitive, psychomotor, and affective by learning heuristic strategies menngunakan higher than in accordance with SBC learning SMA N 9 Padang. This is because the heuristic stretegi guided students to be able to find its own concept of the subject matter. Keywords: Heuristics, Learning Outcomes, Student Worksheet

Abstrak

Penelitian ini dilatarbelakangi oleh kenyataan bahwa pembelajaran fisika di sekolah masih bersifat teacher centre dan hasil belajar fisika masih rendah, padahal fisika merupakan salah satu ilmu yang mendasari perkembangan ilmu pengetahuan dan teknologi. Berbagai macam usaha telah dilakukan oleh pemerintah, namun hasilnya belum maksimal, satu dintaranya adalah penggunaan strategi pembelajaran yang bersifat student centre dan menarik. Salah satu bentuk strategi pembelajaran yang tepat digunakan dalam pembelajaran fisika untuk meningkatkan hasil belajar fisika adalah strategi heuristik. Jenis penelitian yang digunakan adalah kuasi eksperimen dengan penelitian menggunakan Randomized Control Group Only Design. Pemilihan sampel menggunakan teknik Purposif Sampling. Instrumen pengumpul data dalam penelitian ini adalah tes tertulis berupa 25 soal berbentuk pilihan ganda untuk ranah kognitif, rubrik penskoran untuk ranah psikomotor, dan format penilaian untuk ranah afektif. Berdasarkan analisis data yang telah dilakukan, maka ditemukan nilai rata-rata fisika siswa pada ranah kognitif, ranah psikomotor, dan ranah afektif dengan pembelajaran menngunakan strategi heuristik lebih tinggi dari pada pembelajaran sesuai dengan KTSP SMA N 9 Padang. Hal ini disebabkan karena pada stretegi heuristik siswa dibimbing untuk dapat menemukan sendiri konsep dari materi pelajaran.
\end{abstract}

Kata kunci: Heuristik, Hasil Belajar, Lembar Kerja Siswa (LKS)

\section{PENDAHULUAN}

Peningkatan mutu pendidikan berarti juga peningkatan kualitas sumber daya manusia. Sehingga perlu dilakukan pembaharuan dalam bidang pendidikan dari waktu ke waktu tanpa henti. Untuk melakukan hal tersebut, 
pemerintah selalu berusaha untuk meningkatkan mutu pendidikan melalui berbagai cara. Adapun usaha yang telah dilakukan pemerintah dalam meningkatkan kualitas pendidikan fisika diantaranya adalah perbaikan dan pengembangan kurikulum, yakni kurikulum 1994 menjadi Kurikulum Berbasis Kompetensi (KBK) dan sekarang disempurnakan lagi menjadi Kurikulum Tingkat Satuan Pendidikan (KTSP). Usaha peningkatan mutu guru melalui kegiatan penataran, pelatihan, seminar, dan sejenisnya, usaha lainnya yaitu dengan melengkapi sarana dan prasarana pendidikan serta pengadaan buku-buku penunjang. Usaha untuk meningkatkan kualitas pendidikan fisika juga turut dilakukan oleh para guru fisika. Adapun usaha yang dilakukan adalah dengan menerapkan metode pembelajaran yang bervariasi atau tidak monoton. Walaupun masih jarang sekali ditemukan di lapangan atau belum terlaksana sepenuhnya.

Berdasarkan pengamatan penulis di SMA N 9 Padang hal ini terjadi karena kurangnya penguasaan konsep fisika itu bagi siswa. Siswanya cenderung untuk menghafal dan tidak memahami atau memaknai pelajaran fisika, disamping itu juga rendahnya kreatifitas serta keaktifan siswa dalam proses pembelajaran. Situasi pembelajaran di kelas pada umumnya terpusat pada guru, siswa hanya mendengarkan penjelasan guru lalu mencatanya dan juga menghafal tanpa memahami konsep fisisnya. Padahal berdasarkan kurikulum yang digunakan sekarang yaitu Kurikulum Tingkat Satuan Pendidikan (KTSP) menuntut pembelajaran itu berpusat pada siswa (student centre). Oleh karena itu perlu dilakukan suatu usaha yang dapat meningkatkan keaktifan dan motivasi siswa agar dapat terciptanya suasana belajar yang menyenangkan dan bersifat student centre bukan teacher centre.

Untuk memecahkan permasalahan di atas, perlu dilakukan suatu usaha untuk membuat suasana pembelajaran menjadi lebih menarik dan menyenangkan yang bersifat student centre sesuai dengan tuntutan kurikulum. Siswa diberi kesempatan untuk mengembangkan aktivitasnya dalam kegiatan pembelajaran. Tugas guru adalah menciptakan situasi dan kondisi yang dapat membuat siswa terlibat secara aktif selama proses pembelajaran berlangsung, dengan arti kata guru hanya sebagai fasilitator, motivator dan organisator.

Salah satu usaha yang dapat diterapkan peneliti untuk mengatasi masalah yang telah dikemukakan adalah dengan menerapkan strategi heuristik dalam pembelajaran fisika. Heuristik berasal dari bahasa yunani, yaitu heuriskein yang berarti "saya menemukan". Jadi strategi heuristik ini merupakan strategi pembelajaran yang menekankan kepada proses mencari dan menemukan. Materi pelajaran tidak diberikan secara langsung. Peran siswa dalam strategi ini adalah mencari dan menemukan sendiri konsep dari materi pelajaran, sedangkan guru berperan sebagai fasilitator dan pembimbing siswa untuk belajar. Untuk mewujudkan siswa belajar mandiri dalam menemukan konsep dari materi pelajaran tidaklah mudah karena mereka sudah terbiasa dalam pembelajaran yang berpusat pada guru. Agar siswa terarah dalam merumuskan suatu konsep, siswa perlu dibekali dengan pemberian tugas rumah yaitu meringkas materi yang akan dipelajari sehingga membantu mereka memahami konsep pelajaran sebelum materi tersebut dipelajari.

\section{Kurikulum tingkat Satuan Pendidikan (KTSP)}


Undang-Undang Republik Indonesia No 20 Tahun 2003 tentang sistem Pendidikan Nasional, Khususnya pasal 3 menyatakan :

"Pendidikan Nasional berfungsi mengembangkan kemampuan dan membentuk watak serta peradaban bangsa yang bermartabat dalam rangka mencerdaskan kehidupan bangsa, bertujuan untuk berkembangnya potensi peserta didik agar menjadi manusia yang beriman dan bertaqwa kepada Tuhan Yang Maha Esa, berakhlak ,mulia, sehat, berilmu, cakap, kreatif dan mandiri dan menjadi warga negara yang demokratis dan bertanggung jawab".

Saat ini sistem pendidikan nasional Indonesia telah menetapkan kurikulum 2006 atau lebih dikenal dengan Kurikulum Tingkat Satuan Pendidikan (KTSP) yang merupakan sebuah penyempurnaan dari Kurikulum Berbasis Kompetensi (KBK). KTSP adalah sebuah kurikulum operasional pendidikan yang disusun oleh dan dilaksanakan di masing-masing satuan pendidikan. KTSP secara yuridis diamanatkan oleh Undang-Undang Nomor 20 Tahun 2003 tentang Sistem Pendidikan Nasional dan Peraturan Pemerintah Republik Indonesia Nomor 19 Tahun 2005 tentang Standar Nasional Pendidikan. Penyusunan KTSP oleh sekolah dimulai tahun ajaran 2006/2007 dengan mengacu pada Standar Isi (SI) dan Standar Kompetensi Lulusan (SKL) untuk pendidikan dasar dan menengah sebagaimana yang diterbitkan melalui Peraturan Menteri Pendidikan Nasional masing-masing Nomor 22 Tahun
2006 dan Nomor 23 Tahun 2006, serta Panduan Pengembangan KTSP yang dikeluarkan oleh BSNP.

Pada prinsipnya, KTSP merupakan bagian yang tidak terpisahkan dari SI, namun pengembangannya diserahkan kepada sekolah agar sesuai dengan kebutuhan sekolah itu sendiri. KTSP terdiri dari tujuan pendidikan tingkat satuan pendidikan, struktur dan muatan kurikulum tingkat satuan pendidikan, kalender pendidikan, dan silabus.

Pemberlakuan

KTSP sepenuhnya diserahkan kepada sekolah, dalam arti tidak ada intervensi dari Dinas Pendidikan. Penyusunan KTSP selain melibatkan guru dan karyawan juga melibatkan komite sekolah serta bila perlu para ahli dari perguruan tinggi setempat.

Berpijak dari pengertian ini guru dan pihak sekolah diberi wewenang yang luas untuk menyusun sendiri kurikulum (materi pembelajaran) dengan berpegangan pada standar isi dan standar kululusan serta panduanpanduan yang telah disusun oleh Badan Standar Nasional Pendidikan (BNSP). Menurut Mulyasa (2006:22) tujuan dari KTSP adalah:

a. Meningkatkan mutu pendidikan melalui kemandirian dan inisiatif sekolah dalam mengembangkan kurikulum, mengelola dan memberdayakan sumber daya yang telah tersedia.

b. Meningkatkan kepedulian warga sekolah dan masyarakat dalam pengembangan kurikulum melalui 


\section{pengambilan keputusan bersama. \\ c. Meningkatkan kompetensi yang sehat antar satuan pendidikan tentang kualitas pendidikan yang akan dicapai.}

\section{Hasil Belajar}

Kurikulum Tingkat Satuan

Pendidikan dalam melakukan penilaian menerapkan sistem penilaian berkelanjutan yang mencakup tiga ranah yaitu ranah kognitif, ranah psikomotor dan ranah afektif.
a. Ranah Kognitif
Ranah kemampuan
memahami, menghafal, mengaplikasi, menganalisis, mensintesis dan kemampuan mengevaluasi. Menurut Taksonomi Bloom, ranah kognitif terdiri atas enam tingkatan dengan aspek belajar yang

berbeda-beda. Keenam tingkat tersebut yaitu:

1) Tingkat pengetahuan (knowledge).

2) Tingkat pemahaman (comprehension).

3) Tingkat penerapan (application).

4) Tingkat analisis (analysis),

5) Tingkat sintesis (synthesis).

6) Tingkat evaluasi (evaluation).

Hasil belajar ranah kognitif yang digunakan pada penelitian ini disusun berdasarkan indikator materi pelajaran dan strategi pembelajaran heuristik yaitu tingkat pengetahuan (knowledge), tingkat pemahaman (comprehension), tingkat penerapan (application), dan tingkat analisis (analysis). Hal ini dilakukan karena untuk tingkat sintesis (synthesis) dan tingkat evaluasi (evaluation) sangat sulit bagi siswa untuk memecahkanya.

\section{b. Ranah Psikomotor}

Menurut Bloom ranah psikomotor berhubungan dengan hasil belajar yang pencapaiannya melalui keterampilan manipulasi yang melibatkan otot. Ranah psikomotor adalah ranah yang berhubungan aktivitas fisik, misalnya; menulis, memukul, melompat dan lain sebagainya. Ranah psikomotor merupakan salah satu aspek yang penting untuk diketahui oleh guru. Perkembangan ranah psikomotor melalui beberapa tahap. Tahaptahap tersebut antara lain:

1) Tahap kognitif

Tahap ini ditandai dengan adanya gerakan-gerakan yang kaku dan lambat. Ini terjadi karena peserta didik masih dalam taraf belajar untuk mengendalikan gerakan-gerakannya. Dia harus berfikir sebelum melakukan suatu gerakan. Pada tahap ini peserta didik sering membuat kesalahan dan kadang-kadang terjadi tingkat frustasi yang tinggi.

2) Tahap asosiatif Pada tahap ini, seorang peserta didik membutuhkan waktu yang lebih pendek untuk memikirkan tentang gerakan-gerakannya. Dia mulai dapat mengasosiasikan gerakan yang sedang dipelajarinya dengan gerakan yang sudah dikenal. Tahap ini masih dalam tahap pertengahan 


\begin{abstract}
dalam perkembangan psikomotor. Oleh karena itu, gerakan-gerakan pada tahap ini belum merupakan gerakan-gerakan yang sifatnya otomatis. Pada tahap ini, seorang peserta didik masih menggunakan pikirannya untuk melakukan suatu gerakan tetapi waktu yang diperlukan untuk berfikir lebih sedikit dibanding pada waktu dia berada pada tahap kognitif. Dan karena waktu yang dibutuhkan untuk berfikir lebih pendek, gerakangerakannya mulai tidak kaku.
\end{abstract}

3) Tahap otonomi

Pada tahap ini, seorang peserta didik telah mencapai tingkat autonomi yang tinggi. Proses belajarnya sudah hampir lengkap meskipun dia tetap dapat memperbaiki gerakan-gerakan yang dipelajarinya. Tahap ini disebut tahap autonomi karena peserta didik sudah tidak memerlukan kehadiran instruktur untuk melakukan gerakangerakan. Pada tahap ini, gerakan-gerakan telah dilakukan secara spontan dan oleh karenanya gerakan-gerakan yang dilakukan juga tidak mengharuskan peserta didik untuk memikarkan gerakannya.

Hasil belajar ranah psikomotor yang digunakan pada penelitian ini disusun berdasarkan indikator materi pelajaran dan strategi pembelajaran heuristik adalah yang mencakup aktivitas fisik diantaranya meletakkan, menarik, merapikan, menyusun, menimbang, dan lain sebagainya.

\section{c. Ranah Afektif}

Keberhasilan proses pembelajaran fisika juga ditentukan oleh pemahaman tentang perkembangan ranah afektif peserta didik. Ranah afektif tersebut mencakup emosi atau perasaan yang dimiliki oleh setiap peserta didik. Bloom (Brown, 2000) memberikan definisi tentang ranah afektif terbagi atas lima tataran afektif yang implikasinya dalam peserta didik lebih kurang sebagai berikut:

1) Sadar akan situasi, fenomena masyarakat, dan objek sekitar

2) Responsif terhadap stimulus-stimulus yang ada di lingkungan mereka

3) Bisa menilai

4) Sudah mulai bisa mengorganisir nilai-nilai dalam suatu sistem, dan menentukan hubungan diantara nilai-nilai yang ada

5) Sudah mulai memiliki karakteristik dan mengetahui karakteristik tersebut dalam bentuk sistem nilai.

Hasil belajar ranah afektif yang digunakan pada penelitian ini disusun berdasarkan indikator materi pelajaran dan strategi pembelajaran heuristik yaitu disiplin, mengemukakan pendapat, ulet atau tidak cepat putus asa, kritis, rasa ingin tahu, dan sifat saling menghargai. 


\section{Strategi Heuristik}

Strategi pembelajaran

Heuristik adalah rangkaian kegiatan pembelajaran yang menekankan pada proses berpikir secara kritis dan analitis untuk mencari dan menemukan sendiri jawaban dari suatu masalah yang dipertanyakan. Menurut Sanjaya (2006:194) ada beberapa hal yang menjadi ciri utama strategi pembelajaran heuristik, yakni:

a. Strategi ini menekankan pada aktivitas siswa secara maksimal untuk mencari dan menemukan, artinya strategi pembelajaran heuristik menempatkan siswa sebagai subjek belajar. Dalam proses pembelajaran, siswa tidak hanya berperan sebagai penerima pelajaran melalui penjelasan guru secara verbal, tetapi mereka berperan untuk menemukan sendiri inti dari materi pelajaran itu sendiri.

b. Seluruh aktivitas yang dilakukan siswa diarahkan untuk mencari dan menemukan jawaban sendiri dari sesuatu yang dipertanyakan, sehingga diharapkan dapat menumbuhkan sikap percaya diri (self belief). Dengan demikian, strategi pembelajaran heuristik menempatkan guru bukan sebagai sumber belajar, akan tetapi sebagai fasilitator dan motivator belajar siswa.

c. Tujuan dari penggunaan strategi pembelajaran heuristik adalah mengembangkan kemampuan berfikir secara sistematis, logis, dan kritis, atau mengembangkan kemampuan intelektual sebagai bagian dari proses mental. Dengan demikian , dalam strategi pembelajaran heuristik siswa tidak hanya dituntut agar menguasai materi pelajaran, akan tetapi bagaimana mereka dapat menggunakan potensi yang dimilikinya.

Strategi pembelajaran heuristik merupakan bentuk dari pendekatan pembelajaran yang berorientasi kepada siswa (student centered approach). Dikatakan demikian, sebab dalam strategi ini siswa memegang peran yang sangat dominan dalam proses pembelajaran.

Langkah-langkah

pelaksanaan strategi pembelajaran heuristik adalah :

\section{a. Orientasi}

Langkah orientasi adalah langkah untuk membina suasana atau iklim pembelajaran yang responsif. Pada langkah ini guru mengondisikan agar siswa siap melaksanakan proses pembelajaran. Beberapa hal yang dapat dilakukan dalam tahap orientasi ini adalah:

1) Menjelaskan topik, tujuan, dan hasil belajar yang diharapkan dapat dicapai oleh siswa

2)Menjelaskan pokok-pokok kegiatan yang harus dilakukan oleh siswa untuk mencapai tujuan. Pada tahap ini dijelaskan langkah-langkah heuristik serta tujuan setiap langkah, mulai dari langkah merumuskan masalah sampai dengan merumuskan kesimpulan.

3) Menjelaskan pentingnya topik dan kegiatan belajar. Hal ini dilakukan dalam rangka memberikan motivasi belajar siswa.

b. Merumuskan masalah

Merumuskan masalah merupakan langkah membawa siswa pada suatu persoalan yang 
mengandung

teka-teki.

Persoalan yang disajikan adalah persoalan yang menantang siswa untuk berfikir memecahkan teka-teki itu. Beberapa hal yang harus diperhatikan dalam merumuskan masalah, diantaranya:

1) Masalah hendaknya dirumuskan sendiri oleh siswa, guru hanya memberikan topik yang akan dipelajari.

2) Masalah yang dikaji adalah masalah yang mengandung teka-teki yang jawabannya pasti.

3) Konsep-konsep dalam masalah adalah konsepkonsep yang sudah diketahui terlebih dahulu oleh siswa.

c. Merumuskan hipotesis

Hipotesis adalah jawaban sementara dari suatu permasalahan yang sedang dikaji salah satu cara yang dapat dilakukan guru untuk mengembangkan

kemampuan menebak (berhipotesis) pada setiap anak adalah dengan mengajukan berbagai pertanyaan yang dapat mendorong siswa untuk dapat merumuskan jawaban sementara atau dapat merumuskan berbagai perkiraan kemungkinan jawaban dari suatu permasalahan yang di kaji.

d. Mengumpulkan data

Mengumpulkan data adalah aktifitas menjaring informasi yang dibutuhkan untuk menguji hipotesis yang diajukan. Tugas dan peranan guru dalam tahapan ini adalah mengajukan pertanyaan-pertanyaan yang dapat mendorong siswa untuk berfikir mencari informasi yang dibutuhkan.

d. Menguji hipotesis

Menguji hipotesis adalah proses menentukan jawaban yang dianggap diterima sesuai dengan data atau informasi yang diperoleh berdasarkan pengumpulan data

e. Merumuskan kesimpulan

Merumuskan kesimpulan adalah proses mendeskripsikan temuan yang diperoleh berdasarkan hasil pengujian hipotesis. Untuk mencapai kesimpulan yang akurat sebaiknya guru menunjukkan pada siswa data mana yang relevan.

(Wina 2002:201)

\section{Lembar Kerja Siswa (LKS)}

Lembar kerja siswa (LKS) ialah lembar kerja yang berisi informasi dan perintah/instruksi dari guru kepada siswa untuk mengerjakan suatu kegiatan belajar dalam bentuk kerja, praktek, atau dalam bentuk penerapan hasil belajar untuk mencapai suatu tujuan". LKS dibedakan dua macam, yakni LKS eksperimen dan LKS non eksperimen. Dalam penelitian ini, LKS yang digunakan adalah LKS eksperimen.

$$
\text { Menurut Depdiknas }
$$

(2004: 56) dalam menyusun sebuah LKS dilakukan langkahlangkah sebagai berikut:

a. Analisis kurikulum

b.Menyusun peta kebutuhan LKS

c. Menentukan judul LKS 
d.Penulisan LKS
Penulisan LKS dilakukan dengan langkah - langkah sebagai berikut:

1). Perumusan kompetensi dasar yang harus dikuasai

2). Menentukan alat penilaian

3). Penyusunan materi

4). Struktur LKS

Struktur LKS secara umum adalah sebagai berikut:
a) Judul
b) Petunjuk belajar
c) Kompetesi yang akan dicapai
d) Informasi pendukung
e) Tugas- tugas dan langkah
f) Penilaian

\section{METODE PENELITIAN}

Jenis penelitian ini adalah penelitian kuasi eksperimen dengan penelitian menggunakan Randomized Control Group Only Design. Populasi yang digunakan dalam penelitian ini adalah seluruh siswa kelas $\mathrm{X}$ SMAN 9 Padang yang terdaftar pada semester I tahun ajaran 2009/2010.

Pemilihan sampel yang dilakukan dalam penelitian ini adalah dengan menggunakan teknik Purposif Sampling. Teknik ini merupakan teknik pengambilan sampel berdasarkan tujuan tertentu, yaitu kelas sampel yang diajar oleh guru yang sama. Kelas yang diambil sebagai kelas sampel adalah kelas $\mathrm{X}$ ${ }_{2}$ dan $\mathrm{X}_{3}$

Variabel dalam penelitian ini tediri dari variabel bebas, variabel terikat, dan variabel kontrol. Variabel bebas yaitu pembelajaran dengan penerapan strategi heuristik menggunakan LKS. Variabel terikat yaitu hasil belajar fisika siswa.

Variabel kontrol adalah guru, mata pelajaran, buku sumber dan jumlah jam pelajaran yang diberikan adalah sama.

Instrumen yang digunakan dalam penelitian ini yaitu tes objektif untuk ranah kognitif, rubrik penskoran untuk ranah psikomotor, format penilaian untuk ranah afektif.

\section{HASIL DAN PEMBAHASAN}

\section{A. Hasil Penelitian}

\section{a). Ranah Kognitif}

Dari tes hasil belajar diperoleh kelas eksperimen memperoleh nilai tertinggi 88 dan nilai terendah 52. Sedangkan pada kelas kontrol, nilai tertinggi 80 dan nilai terendah 48 .

\section{b). Ranah Psikomotor}

Sama halnya dengan ranah kognitif bahwa nilai rata-rata ranah psikomotor pada kelas eksperimen lebih tinggi dari pada kelas kontrol. Nilai tertinggi ada pada kelas eksperimen yaitu 93 dan nilai terendah terdapat pada kelas kontrol yaitu 63 .

\section{c). Ranah Afektif}

Pada ranah kognitif nilai yang diperoleh cukup bervariasi, sama dengan ranah kognitif dan ranah psikomotor bahwa nilai rata-rata untuk ranah afektif pada kelas eksperimen lebih tinggi dari pada kelas kontrol. Nilai tertinggi ada pada kelas eksperimen yaitu 94 dan nilai terendah terdapat pada kelas kontrol yaitu 52

\section{B. Pembahasan}

Dari hasil penelitian yang dilakukan pada kedua kelas sampel dapat dilihat bahwa terdapat perbedaan hasil belajar fisika siswa pada ranah kognitif antara kelas eksperimen dalam penerapan strategi heuristik pada 
pembelajaran fisika dengan kelas kontrol dalam pembelajaran sesuai dengan Kurikulum SMA N 9 Padang. Hal ini dapat dilihat dari hasil tes akhir belajar fisika, dimana nilai rata-rata pada kelas eksperimen 68,55 sedangkan pada kelas kontrol 61,11. Dari hal ini dapat disimpulkan bahwa nilai rata-rata kelas eksperimen lebih tinggi daripada kelas kontrol.

Setelah data dianalisis, kedua kelas sampel berasal dari populasi yang terdistribusi normal dan memiliki varians yang homogen, kemudian dilakukan analisis uji $t$ untuk pengujian hipotesis. Dari hasil analisis diperoleh $t_{\mathrm{H}}$ adalah 0,55 dan $t_{\text {tabel }}$ adalah 1,998 dimana harga $t_{H}$ ini berada diluar daerah peneriman $\mathrm{H}_{0}$, sehingga $\mathrm{H}_{0}$ ditolak dan $\mathrm{H}_{\mathrm{i}}$ diterima, yang menunjukkan adanya pengaruh penerapan strategi heuristik pada pembelajaran fisika terhadap hasil belajar fisika siswa kelas $\mathrm{X}$ SMA N 9 Padang.

Begitu pula untuk ranah psikomotor dan ranah afektif yang datanya diolah secara kualitatif, menunjukkan bahwa hasil belajar pada kelas eksperimen lebih tinggi dari pada kelas kontrol. Hal ini menunjukkan bahwa strategi heuristik dalam pembelajaran fisika berpengaruh terhadap hasil belajar fisika siswa.

Strategi pembelajaran heuristik adalah rangkaian kegiatan pembelajaran yang menekankan pada proses berpikir secara kritis dan analitis untuk mencari dan menemukan sendiri jawaban dari suatu masalah yang dipertanyakan. Strategi pembelajaran heuristik merupakan bentuk dari pendekatan pembelajaran yang berorientasi kepada siswa (student centered approach). Dikatakan demikian, sebab dalam strategi ini siswa memegang peran yang sangat dominan dalam proses pembelajaran.

Berdasarkan penelitian yang telah dilakukan dan data yang telah diperoleh dapat dibuktikan bahwa strategi pembelajaran heuristik merupakan salah satu bentuk pembelajaran yang bersifat student center, karena pada strategi pembelajaran ini banyak dituntut peran siswa dalam mengolah atau memahami materi pelajaran sementara guru hanya bertindak sebagai motivator dan fasilitator. Sehingga dalam pembelajaran dengan menggunakan strategi heuristik ini dapat meningkatkan kreatifitas dan hasil belajar fisika siswa. Hal ini sesuai dengan pendapat Wina Sanjaya yang menyatakan bahwa strategi pembelajaran heuristik merupakan bentuk dari pendekatan pembelajaran yang berorientasi kepada siswa (student centered approach). Dikatakan demikian, sebab dalam strategi ini siswa memegang peran yang sangat dominan dalam proses pembelajaran.

Berdasarkan penelitian yang telah dilakukan maka nilai rata-rata tes akhir untuk ranah kognitif siswa kelas eksperimen lebih tinggi daripada kelas kontrol. Begitu juga pada ranah 
psikomotor dan ranah afektif kelas eksperimen lebih baik dari pada kelas kontrol. Penerapan strategi heuristik dalam pembelajaran fisika dapat meningkatkan hasil belajar fisika siswa pada ranah kognitif, ranah psikomotor, dan ranah afektif.

\section{KESIMPULAN}

Setelah melakukan analisis dan pembahasan terhadap masalah yang telah dikemukakan dalam penelitian ini, dapat disimpulkan beberapa hal yaitu:

1. Nilai rata-rata hasil belajar fisika siswa pada ranah kognitif, ranah psikomotor dan ranah afektif dengan penerapan strategi heuristik lebih tinggi dari pada nilai rata-rata hasil belajar fisika siswa dengan pembelajaran sesuai Kurikulum SMAN 9 Padang.

2. Terdapat pengaruh yang berarti dari penerapan strategi heuristik pada pembelajaran fisika terhadap hasil belajar fisika siswa kelas X SMA N 9 Padang pada ranah kognitif dengan taraf nyata $95 \%$, dan pada ranah psikomotor serta ranah afektif.

3. Berdasarkan indikator kinerja, maka usaha yang dilakukan dapat dikatakan berhasil. Karena hasil belajar fisika siswa pada ranah kognitif, ranah psikomotor, dan ranah afektif dengan menggunakan strategi heuristik telah memenuhi Kriteria Ketuntasan Minimum (KKM) untuk mata pelajaran fisika di SMA N 9 Padang yaitu diatas 62 .

\section{DAFTAR PUSTAKA}

Arikunto, Suharsimi. (2003). Dasar-
Dasar Evaluasi Pendidikan

. Jakarta: Bumi Aksara.

Depdiknas. (2004). Pedoman Umum Pengembangan Bahan Ajar SMA. Jakarta: Dikjen Pendidikan Dasar Menengah. www.ktspdiknas.go.id. Diakses Tanggal 15 Oktober 2009. . (2006). Kurikulum Tingkat Satuan Pendidikan (KTSP). Jakarta: Dikjen

Dikdakmen.

Pelajaran IPA SMP \& MTS,
Fisika SMA \& MA. Jakarta:
Dikjen Pendidikan Dasar dan
Menengah.
www.ktspdiknas.go.id. Diakses
Tanggal 15 Oktober 2009.

Mulyasa. (2006). Kurikulum Tingkat

Satuan Pendidikan Suatu

Pendektan Praktis. Bandung:

Remaja Rosdakarya.

Sanjaya, W. (2007). Starategi

Pembelajaran Berorientasi

Standar Proses Pendidikan.

Jakarta: Kencana Prenada

Media

Group.

UURI No. 20 Tahun 2003. Tentang

Sistem Pendidikan Nasional. Jakarta: Depdiknas RI. 